\title{
The Development of Electronic Practicum Modules at Electronic Course for Physics Education Program
}

\author{
Muhammad Amin Said ${ }^{\text {a)}}$, Muhammad Arsyad ${ }^{\text {b) }}$, Muh. Tawil ${ }^{\text {c) }}$ \\ Department of Physics Education Postgraduate Program at Universitas Negeri Makassar \\ Jalan Bonto Langkasa, Banta-Bantaeng, Kec. Rappocini, Kota Makassar, Sulawesi Selatan, 90222, \\ Indonesia \\ : ${ }^{a}$ muhamin@unismuh.ac.id, b)m_arsyad288@unm.ac.id, ${ }^{\mathrm{c})}$ muh.tawil@unm.ac.id
}

\begin{abstract}
This study aimed to design a practicum module in electronics courses. The researcher initially carried out the developed module to analyze the level of validity and students' responses to the electronic practicum module that the researcher had created. The module developed was validated by two experts. The subjects of this research were students of the Physics Education Program at the Muhammadiyah University of Makassar in the odd semester in the academic year of 2019/2020. This research employed a Research and Development (R\&D) design. The development was carried out using the 4D model with four stages: Define, Design, Develop and Disseminate proposed by Thiagarajan. The results showed that the expert assessment of the electronic practicum module that had been developed using the Gregory test closeness model obtained a strong relevance level because it had an internal consistency coefficient of $100 \%$ and was declared to meet the eligibility criteria (valid). The percentages of students' responses in the three indicators (interested in using the module, easy to understand the module content and easyto-understand module language) were $83 \%, 81 \%$, and $81 \%$, respectively. Based on the description above, it can be concluded that the electronic practicum module developed is declared valid, and students respond well to the use of the electronics practicum module.
\end{abstract}

Keywords: electronics practicum, module development, research and development

\section{INTRODUCTION}

Science and technology are experiencing rapid development in this globalization era. This development continued to increase and profoundly affected society, both directly and indirectly (Said, Arsyad, \& Nurlina 2015). For this reason, educated people who can master and adapt to the development of science and technology are absolutely needed to reflect on the lack of developing content knowledge of technology education (Tsai et al. 2021). Indonesia was one of the countries that kept developing science and technology, including education. Moreover, one indicator from which people can measure the quality of education in higher education is the success in the learning process (Gunawan, Setiawan, \& Widyantoro 2013).

Success in learning was very dependent on learning resources or media used during the learning process. According to Mulyasa (2004), learning resources can be formulated as anything that can convenience students in obtaining much information, knowledge, experience (Amir, Muris, \& Arsyad 2015), and skills in the teaching and learning process. So, the development and application of media in modules to support the learning process was very much required (Dewi, Sunarno, \& Sarwanto 2018). It was hoped that the presentation of the material in the module was not complicated by students, 
making it easier for them to understand the concepts and materials (Alias \& Siraj 2012). The module is also expected to present examples of cases and problems with solutions to help make it easier for them to understand the concepts being studied (Bakri, Rasyid \& Mulyaningsih 2015).

In the learning process, the selection of strategies, models, methods, or learning skills can also influence the success of the learning process. By using appropriate learning tools and strategies, learners will achieve goals well. (Nurrohman, Suyatno \& Ertikanto 2013) Conducted research using interview analysis techniques, giving questionnaires on students' needs, and designing a development product by collecting proven source material, making questions and answers, and selecting indicators of generic science skills displayed on every activity in the Students' Worksheets (Prastowo 2012). The samples of research Nurrohman, Suyatno, \& Ertikanto were class VIII students, consisting of 32 people. The students were given a treatment in the learning process by using the worksheets that have been developed and were given a questionnaire to describe the worksheets' attractiveness, convenience, and usefulness. Thus, KGS-based worksheets are feasible and effective to be used as learning media.

Based on the preliminary observations done at the physics Education Study Program of the Muhammadiyah University of Makassar, it was known that the students still found it difficult to implement the current practicum methods. The problems experienced by students were 1) the current practicum modules were still lacking of learning materials regarding the introduction of basic tools and materials in practicum as well as theories included in the practice module; 2) the module used today described the procedures whose steps were difficult to understand; 3) the practicum module was not yet completed with practice questions, so students tended to follow only what was written in the module and learning become meaningless.

In addition, the laboratory assistants also admitted that when carrying out the practicum, the students' obtained low scores. Moreover, there was also a decrease in attitude. The students of Physics Educations Study Program Universitas Muhammadiyah Makassar showed a lack of confidence and were less motivated to analyze the construction and preferred to accept what was explained by the assistant (Tawil \& Liliasari 2016). Regarding process skills, the students who used old modules tended to be less creative in carrying out the practicum, so they became passive to think creatively. According to (Solihan, Astra \& Budi 2018), Things that can be achieved by conducting practical activities in the laboratory are: 1) Acquisition of skills, including observing, investigating, manipulating, organizing and communicating; 2) Increased cognitive abilities, such as the ability to think critically, solve problems, analyze and synthesize; 3) increased attitudes, such as curiosity, courage to take risks, confidence, independence, satisfaction, and responsibility (Nawawi, Antika, Wijayanti, \& Abadi 2017).

One effort to overcome the above problems was to develop innovative teaching material in a practicum module that was easy to understand, not student worksheets. Modules were teaching materials compiled systematically and attractively containing lessons, methods, and evaluation and can be used independently to achieve the predetermined indicators. While the student worksheet, which includes assignments that students must do. Student worksheets are usually in the form of instructions, steps to complete a task (Syamsidar, Khaeruddin, \& Helmi 2021).

Practicum modules became very important to support learning and emphasize aspects of the process. This process can train students' skills in education. This was in line with Marbun, Nehru \& Syakowi's (2017) research, which employed interview and questionnaire sheets analysis. The sample of the study was the

Physics Education students of Jambi University in the academic year of 2014/2015. The students were treated using a development module in the practicum process and were given an interview and questionnaire sheets. The results showed that the practicum module developed was suitable for being used as one of the learning media in implementing the Basic Electronics I practicum.

Based on the problem description above, the researcher was interested in developing Electronic Practicum Modules at the physics education study program at the Muhammadiyah University of Makassar. 


\section{METHODS}

The type of research is categorized as developmental research in which the research design refers to the 4-D development model (Sivasailan \& Thiagarajan, 1974), which consists of four stages. These stages consist of:

1. Defining, at this stage, was to determine and define the learning requirements.

2. Design, at this stage, to design learning device prototypes.

3. Development, at this stage, was to produce a prototype learning device.

4. Deployment: There are three activities at this stage: validation testing, packaging, diffusion, and adoption.

The subjects of this research were class 2018 A students in the odd semester of the academic year of 2019/2020 at the Physics Education Study Program Universitas Muhammadiyah Makassar. In this research, the sampling technique used the module validation sheet instrument, the lecturer and laboratory assistant response questionnaire sheet, the student response questionnaire sheet, and the science generic skills performance test sheet (Smaldino, Lowther, \& Russell 2011). The module validation sheet was validated by two experts (in the same expertise) using the Gregory test as follows:

$$
R=\left[\frac{D}{A+B+C+D}\right]
$$

With the following agreement model:

\section{Expert 1}

Weak Relevance Strong Relevance

\section{Expert 2}

$$
\begin{gathered}
\text { Weak Relevance } \\
1-2 \\
\text { Strong Relevance } \\
3-4
\end{gathered}
$$

$$
1-2
$$
$3-4$

\begin{tabular}{|c|c|}
\hline$A$ & $B$ \\
\hline$C$ & $D$ \\
\hline
\end{tabular}

FIGURE 1. Validation Determination Model

(Gregory 2000)

Information:

1 : very inappropriate

$2:$ not appropriate

$3:$ appropriate

4 : very appropriate

The validation determination model in Figure 1 was then put into the cross tabulation TABLE $2 \mathrm{x}$ 2 which can be seen in TABLE 1 .

TABLE 1. Experts' Cross Tabulation ( 2 x 2) Result (Gregory 2000)

\begin{tabular}{cccc}
\hline \multirow{2}{*}{ Expert Assessment Tabulation } & \multicolumn{2}{c}{ Practitioner I } \\
\cline { 2 - 4 } & \multicolumn{2}{c}{$\begin{array}{c}\text { Irrelevant } \\
\text { (score 1 -2) }\end{array}$} & $\begin{array}{c}\text { Relevant } \\
\text { (score 3-4) }\end{array}$ \\
\hline \multirow{3}{*}{ Practitioner II } & $\begin{array}{c}\text { Irrelevant } \\
\text { (score 1 -2) }\end{array}$ & $(1,1)(1,2)(2,1)(2,2)$ & B \\
\cline { 2 - 4 } & $\begin{array}{c}\text { Relevant } \\
\text { (score 3-4) }\end{array}$ & $\begin{array}{c}\text { C } \\
(1,3)(1,4)(2,3)(2,4)\end{array}$ & $(3,1)(3,2)(4,1)(4,2)$ \\
\hline
\end{tabular}

Explanation:

A : Both practitioners did not agree

B : Practitioner I agreed, practitioner II disagreed

C : Practitioner I disagreed, practitioner II agreed

D : Both practitioners agreed 
Meanwhile, the students' responses was assessed using a questionnaire. The questionnaire was distributed after the practicum using the modules had developed. The data used to analyze students' responses were qualitative and quantitative data. The statement on the students' response questionnaire involved negative and positive messages. The students' responses through questionnaires in the form of qualitative values must be converted into quantitative ones. Thus, the researcher used the following rubric (TABLE 2).

TABLE 2. Student Response Questionnaire Conversion Results (Riduwan 2012)

\begin{tabular}{cccc}
\hline Positive Statement & \multicolumn{3}{c}{ Negative Statement } \\
\hline Answer & score & Answer & Score \\
\hline Strongly agree & 4 & Strongly agree & 1 \\
Agree & 3 & Agree & 2 \\
Disagree & 2 & Disagree & 3 \\
Strongly Disagree & 1 & Strongly Disagree & 4 \\
\hline
\end{tabular}

The quantitative data obtained based on the above assessment then analyzed by using the following formula (Sugiono 2015):

$$
\mathrm{P}=\frac{\Sigma A}{\Sigma \boldsymbol{B}} \times 100 \%
$$

Information:

$\mathrm{P} \quad=$ percentage of score earned

$\Sigma \mathrm{A}=$ total score of each item

$\Sigma \mathrm{B}=$ ideal number of scores

\section{RESULTS AND DISCUSSION}

\section{Results of Validation Analysis for Electronic Practicum Modules}

The results of the validators' validation toward the electronic practicum modules that have been developed can be explained as follows.

1. The aspect of contents eligibility consists of 10 items of assessment. The validation results show that the first validator gave a value of 4 for each item, and the second validator tended to give a value of 3 for each item. Using the Gregory test, the module obtained a strong relevance level declared valid.

2. The presentation/display feasibility aspect consists of 6 grading points. The validation process results show that the two validators gave a value of 4 on each item. Therefore, by using the Gregory model, a strong relevance level was obtained and declared valid.

3. The aspect of language eligibility covers 10 points of assessment. The validation results show that the first validator tends to give a value of 4 for each item, and the second validator gives a value of 3 for each item so that by using the Gregory test, a strong relevance level was obtained and declared valid.

4. The aspect of graphics feasibility involves nine evaluation points. The validation results show that the two validators gave a value of 4 on each item so that by using the Gregory model, a strong relevance level was obtained and declared valid.

From the explanation, it can be seen that the electronics practicum module is classified as having strong relevance because it had an internal coefficient of $100 \%$ if the results of this content coefficient $(\mathrm{Rg}>75 \%)$ show that the validation results provided by the validator team have a firm consistency response. So, the electronic practicum module that has been developed is declared to meet the eligibility criteria (valid) to be used with a bit of revision.

\section{Results of Analysis of Students' Responses}

The researcher obtained the students' responses toward the electronics practicum module from the questionnaire sheets after using the module. Collecting the response then scored the questionnaire results. After that, the data was then analyzed using descriptive analysis. The analysis results based on the students' responses about the module had developed can be seen in TABLE 3 . 
TABLE 3. Percentage of Students' Responses toward Practicum Module

\begin{tabular}{llcc}
\hline No & \multicolumn{1}{c}{ Indicator } & $\begin{array}{c}\text { Percentage } \\
(\mathbf{\%})\end{array}$ & Category \\
\hline 1 & $\begin{array}{l}\text { Students' Interest in learning modules } \\
\text { The materials in the learning module is easy to } \\
\text { understand }\end{array}$ & 83 & Very good \\
3 & $\begin{array}{l}\text { The language used in the learning module is easy } \\
\text { to understand }\end{array}$ & 81 & Very good \\
\hline \multicolumn{1}{c}{ Average } & $\mathbf{8 2}$ & Very good \\
\hline
\end{tabular}

From TABLE 3, the result can see that $83 \%$ of the students were interested in using modules that have been developed. $81 \%$ of the students found it easy to understand the material in the modules that have been developed. $81 \%$ of students could easily understand the language used in modules that have been developed, with all indicators being in very good category. Based on the students' assessment of the three indicators above, it can be concluded that the electronics practicum module that the researchers have developed was classified in a very good category with an average percentage of $82 \%$. It means that the students very well received the modules that have been developed. Most of the students gave a good response to the use of the modules in the practicum, whereas their reactions to the use of practicum modules were in very good category.

The summary of the results of the students' responses assessment can be seen in FIGURE 2.

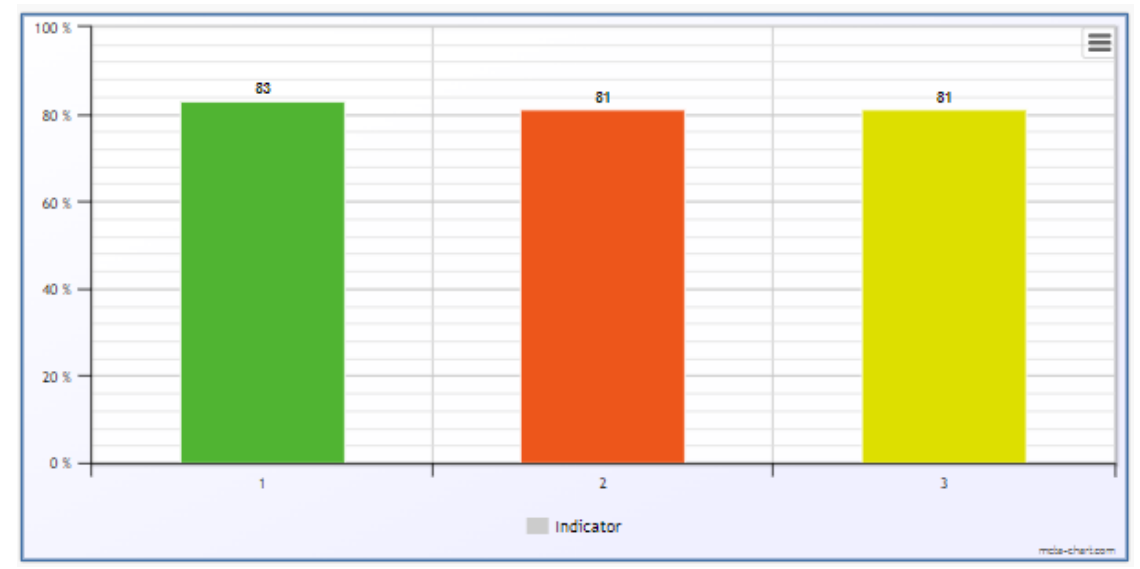

FIGURE 2. Percentage of Students' Responses toward Practicum Module

The responses of students who were in the outstanding category can be used as a benchmark that students felt more comfortable with the teaching materials used in the learning process (Nugraha, Binadja \& Supartono 2013). Based on this statement, the researcher can conclude that the practicum module made the students more comfortable and easy to understand the module's contents. Besides that, very good results were obtained because the practicum method made students feel involved in every learning activity and interact with students. This is in line with the research results by Salawane et al. 2020 which explains that teaching materials that can involve students can make students joyful. The same as in the use of teaching materials in videos that will include a lot of positive interactions with students (Kennedy \& Lees 2016).

This was indicated by the response of students in the very good category. This was also in line with research (Parmin \& Peniati 2013), with the trial being conducted by 25 students of the UNNES Science Education Study Program. The data collected in this study were students' attitudes after using the module. The data collection technique in this study was a student attitude questionnaire towards the modules used to implement learning (Mosik \& Purwantoyo 2013). So, the questionnaire analysis of student responses showed a positive reaction after using the module in education. A total of 18 people $(72 \%)$ of students stated that they were very interested in using the module, while the rest indicated that they were interested so that the use of the module helped students learn. 


\section{CONCLUSION}

Based on the research and discussion that has been done, it can be concluded that the theoretical validity results of the practicum module using the expert validity method show that the module was in the valid category. Using the agreement model in the Gregory test, the assessment results of the two experts were at a level of strong relevance, and the students' responses of Physics Education Study Program Universitas Muhammadiyah Makassar toward the modules that the researchers have developed were in very good category. The new practicum module developed was more comfortable and easier to understand.

\section{REFERENCES}

Alias, N \& Siraj, S 2012, 'Design and Development of Physiscs Module Based On Learning Style and Approriate Technology By Employing Isman Instructional Design Model', Tojet: The Turkish Online Journal of Educational Technology, vol. 11, no. 4, pp. 84-93.

Amir, M, Muris, \& Arsyad, M 2015, 'Pengembangan Perangkat Pembelajaran Berbasis Pengalaman Pada Peserta Didik Kelas XI IPA SMA Negeri 9 Pinrang', Jurnal Sains dan Pendidikan Fisika, vol. 11, no. 3, pp. 202-213.

Bakri, F, Rasyid, R, \& Mulyaningsih, RDA 2015, 'Pengembangan Modul Fisika Berbasis Visual untuk Sekolah Menengah Atas (SMA)', Jurnal Penelitian dan Pengembangan Pendidikan Fisika, vol. 1, no. 2, pp. 67-74.

Dewi, FMC, Sunarno, W \& Sarwanto 2018, 'Pengembangan Modul Fisika Berbasis Masalah pada Materi Termodinamika untuk Meningkatkan Keterampilan Generik Sains Siswa Kelas XI SMA/MA', Jurnal Inkuiri, vol. 7, no. 1.

Gregory, RJ 2000, 'Psychological Testing: History, Principles, and Applications, Boston: Allyn And Baco.

Gunawan, Setiawan, A \& Widyantoro, DH 2013, 'Model Virtual Laboratory Fisika Modern untuk Meningkatkan Keterampilan Generik Sains Calon Guru', Jurnal Pendidikan Dan Pembelajaran, vol. 20, no. 1, pp. 25-32.

Kennedy, AS \& Lees, AT 2016 'Preparing Undergraduate Pre-service Teachers Through Direct and Video-Based Performance Feedback and Tiered Supports in Early Head Start', Early Childhood Educ J vol. 44, pp. 369 - 379.

Marbun, FH, Nehru, \& Syakowi, A 2017, 'Pengembangan Modul Praktikum Berbasis Inkuiri Terstruktur Pada Mata Kuliah Elektronika Dasar 1 Program Studi Pendidikan Fisika Universitas Jambi', Jurnal EduFisika', vol. 2, no. 2, pp. 18-33.

Mosik, NA \& Purwantoyo, E 2013, 'Pengembangan Modul IPA Terpadu Kontekstual pada Tema Bunyi', Unnes Science Education Journal, vol. 2, no. 1, pp. 196-202.

Mulyasa, E 2004, 'Kurikulum Berbasis Kompetensi; Konsep Karakteristik, dan Implementasi', Bandung: Rodya Karya.

Nawawi, S, Antika, RN, Wijayanti, TF \& Abadi, S 2017, 'Pelatihan Pembuatan Modul Ajar Berbasis Kurikulum 2013 untuk Meningkatkan Kemampuan Berpikir Kritis', Prosiding Seminar Nasional Hasil Pengabdian Kepada Masyarakat Tahun 2017, pp. 42-46.

Nugraha, DA, Binadja, A \& Supartono 2013, 'Pengembangan Bahan Ajar Reaksi Redoks Bervisi Sets \& Berorientasi Konstruktivistik', Journal of Innovative Science Education, vol. 2, no. 1, pp. 27-34.

Nurrohman, Suyatno, A \& Ertikanto, C 2013, 'Pengembangan Lembar Kerja Siswa (LKS) Berbasis Keterampilan Generik Sains (KGS) Materi Tekanan', Jurnal Dosen Pendidikan Fisika FKIP Unila, vol. 1, no. 1, pp. 55-66, https://doi.org/10.1017/CBO9781107415324.004. 
Parmin \& Peniati 2013, 'Pengembangan Modul Mata Kuliah Strategi Belajar Mengajar IPA Berbasis Hasil Penelitian Pembelajaran', Jurnal Pendidikan IPA Indonesia, vol. 2, no. 2, pp. 203-208.

Prastowo, A 2012, 'Panduan Kreatif Membuat Bahan Ajar Inovatif', Jogjakarta: DIVA Press.

Riduwan 2012, 'Mudah Penelitian untuk Guru-Karyawan dan Peneliti Pemula', Bandung: Alfabeta.

Said, MA, Arsyad, M, \& Nurlina 2015, 'Penerapan Model Pembelajaran Kooperatif Tipe Scramble dalam Meningkatkan Hasil Belajar Peserta Didik Kelas X SMA Negeri 14 Makassar', Jurnal Pendidikan Fisika, vol. 3, no. 2, pp. 56-63.

Salawane, C, Supriyadi, S, Rusilowati, A, Indriyanti, DR, \& Binadja, A 2020, 'Teaching Material using SETS Approach for Volcanic Dust Disaster Mitigation', Jurnal Penelitian \& Pengembangan Pendidikan Fisika, vol. 6, no. 2, pp. 195 - 202.

Sivasailan \& Thiagarajan 1974, 'Instructional Development for Training Teachers of Exceptional Children: A Sourcebook', Indiana: Indiana University Bloomington.

Smaldino, SE, Lowther, DL \& Russell, JD 2011, 'Instructional Technology and Media for Learning', Jakarta: Kencana Prenada Media Group.

Solihan, Astra, IM, \& Budi, E 2018, 'The Development of Thermal Expansion Practicum Sets to Improve Science Process Skills of High-School Students', Jurnal Penelitian dan Pengembangan Pendidikan Fisika, vol. 4, no. 2, pp. 113-124.

Sugiono 2015, 'Metode Penelitian dan Pengembangan (Research and Development)', Bandung: Alfabeta.

Syamsidar, S, Khaeruddin, K, \& Helmi, H 2021, 'The Effectiveness of using Student Worksheets to Practice Science Process Skills on Hooke's Law Material', Jurnal Penelitian \& Pengembangan Pendidikan Fisika, vol. 7, no. 1, pp. 83 - 90.

Tawil, M \& Liliasari 2016, 'Manajemen Laboratorium IPA. (Muharram, Ed.)', Makassar: Badan Penerbit UNM.

Tsai, FH, Hsiao, HS, Yu, KC, \& Lin KY 2021 'Development and effectiveness evaluation of a STEMbased game-design project for preservice primary teacher education', Int J Technol Des Educ. 5 September 2021. 
